\title{
Effect of Bio-fertilizers on Growth and Leaf Yield of Coriander (Coriandrum sativum L.)
}

\author{
Asim Abhishek Swain*, Debi Archana Nayak, Premananda Mahapatra, \\ Alok Nandi, Nitish Kumar Jena and Janmejaya Panda
}

Department of Horticulture, Faculty of Agricultural Sciences,Siksha "O” Anusandhan

(Deemed To Be University), Bhubaneswar-751029, Odisha, India

*Corresponding author

\section{A B S T R A C T}

\begin{tabular}{|l|}
\hline Keyw or d s \\
$\begin{array}{l}\text { Coriander, } \\
\text { Biofertilizer, } \\
\text { Leaf yield and } \\
\text { growth }\end{array}$ \\
\hline Article Info \\
\hline $\begin{array}{l}\text { Accepted: } \\
\text { 07 March } 2020 \\
\text { Available Online: } \\
\text { 10 April 2020 }\end{array}$ \\
\hline \hline
\end{tabular}

A field experiment was conducted during winter 2018-19 at Instructional farm, S'O'A (Deemed to be University), Bhubaneswar, to study the effect of bio-fertilizers particularly Azotobacter and Azospirillum with inorganic fertilizers like Nitrogen, Phosphorous \& Potash on growth and leaf yield of coriander and to find out the most appropriate combinations of inputs for coriander. The experiment was evaluated in randomized block design. The experiment was composed of ten treatments in various combinations of organic and inorganic fertilizers. Maximum leaf yield (26.22 q/ha) was recorded by using $100 \%$ recommended dose of fertilizers $(60-40-40 \mathrm{~kg} / \mathrm{ha})$ along with bio-fertilizers i.e. Azotobacter (5 kg/ha) and Azospirillum (5 $\mathrm{kg} / \mathrm{ha}$ ). Combined effects of bio-fertilizers along with inorganic chemical fertilizers boosted plant yield attributing characters to exhibit maximum level which in turn produced the highest yield.

\section{Introduction}

Coriander (Coriandrum sativum) also known as cilantro, Chinese parsley or dhania is an annual herb mainly cultivated for fruit (dried seed) as well as for tender green leaves. In India, it is widely cultivated in Rajasthan, UP, Gujarat, Madhya Pradesh and Tamilnadu. The green leaves are good source of Vitamin- A\& C. The young plants are being used in preparation of chutney, curries, soup and sauce due to its aromatic flavour. Leaves and seeds are extensively used as a spice $\&$ food flavouring agents throughout the world (Singh \& Singh, 1996).

Being the land of spices India is foremost country in the world with regard to production of coriander. There is a good demand of coriander in international market as a spice 
(Shreekumar, 1997). Azospirillum and Azotobacter association in combination enhance availability of nitrogen which can assist the host plant to increase the growth (Gaur, 1990). Azospirillum and Azotobacter produce growth promoting hormones like IAA, GA that increase nitrogen content in soil (Prabhu et al., 2001)

In spite of great utility of coriander, little attention has been paid to evolve suitable package of practices for its profitable cultivation. In the recent years, a lot of emphasis has been given on the possibility of utilizing indigenously available bio-fertilizers to meet the nutrient requirement by the crops. Bio fertilizers have emerged as important components of integrated nutrient system which help in improving crop yields by supplying the nutrients in adequate amount.

\section{Materials and Methods}

The field experiment was carried out at the instructional farm of Institute of Agricultural Sciences, Bhubaneswar in the year 201819. The present field experiment was carried out with variety Jajpur Local, Ten treatments were laid out in Randomized Block Design (RBD) with 3replications.A spacing of (15 x 10) $\mathrm{cm}$ was maintained. The fertilizer dose of
60:40:40 N-P-K kg/ha is recommended. Full dose of $\mathrm{P}_{2} \mathrm{O}_{5}$, full dose of $\mathrm{K}_{2} \mathrm{O}$ along with half dose of $\mathrm{N}_{2}$ were applied on plots as basal dose. The rest half of $\mathrm{N}_{2}$ amount was applied in 2 split doses at 15 days interval. Azotobacter@ 5 kg/ha, Azospirillum @ 5 $\mathrm{kg} / \mathrm{ha}$, or combination of both were applied before sowing in the field as per plot layout. Pramukh (19-19-19) was sprayed @ 5 g per liter of water after cutting of the leaves.

Five sample plants from each plot were tagged randomly to record data on growth and yield attributing characters. The experimental data were analyzed statistically by the method of analysis of variance as outlined by Panse and Sukhatme (1985). All other cultural operations were carried out as per recommended package of practices. The $1^{\text {st }}$ cut (Coriander leaves) was given 30 days after sowing of the seeds. Thereafter, two cuttings were given each at 30 days interval.

The mean data and physio-chemical estimates were subjected to proper statistical analysis in randomized block design. The F-tests were used for testing the significance of findings. Standard error for each factor was worked out and to compare the two treatment means, the critical difference (C.D) was calculated at 5\% level of significance.

\section{Treatment Details}

\begin{tabular}{|c|c|}
\hline Notations & Treatments \\
\hline $\mathbf{T}_{1}$ & $100 \%$ RDF (Control) \\
\hline $\mathbf{T}_{2}$ & $100 \%$ RDF+Azotobacter@ 5 kg/ha \\
\hline $\mathbf{T}_{\mathbf{3}}$ & $100 \%$ RDF+Azospirillum @ 5 kg/ha \\
\hline $\mathbf{T}_{4}$ & $100 \% \mathrm{RDF}+$ Azotobacter + Azospirillum \\
\hline $\mathbf{T}_{5}$ & 75 \% RDF + Azotobacter @ 5 kg/ha \\
\hline $\mathbf{T}_{6}$ & $75 \%$ RDF+Azospirillum @ 5 kg/ha \\
\hline $\mathbf{T}_{7}$ & $75 \%$ RDF + Azotobacter + Azospirillum \\
\hline $\mathbf{T}_{8}$ & $50 \%$ RDF+Azotobacter@5 kg/ha \\
\hline $\mathbf{T}_{9}$ & $50 \%$ RDF+Azospirillum @ 5 kg/ha \\
\hline $\mathbf{T}_{10}$ & $50 \% \mathrm{RDF}+$ Azotobacter + Azospirillum \\
\hline \multicolumn{2}{|c|}{ (RDF :- N:P $\mathrm{P}_{2}: \mathrm{K}_{2} \mathrm{O} @ 60-40-40$ kg/ha) } \\
\hline
\end{tabular}




\section{Results and Discussion}

The present investigation is intended to estimate the effects of bio-fertilizers with graded doses of chemical fertilizers like $\mathrm{N}$, Pand $\mathrm{K}$ on the growth and yield of Coriander (Coriandrum sativum L). An integrated approach to nutrient management involving judicious combination of different chemical fertilizers (Nitrogen, Phosphorous and Potash) and bio inoculants (Azotobacter, Azospirillum) on the growth and yield of coriander could be a rewarding approach in this context.

\section{Plant height $(\mathrm{cm})$}

The plant height was recorded in different dates of growth of plant i.e. 30 days, 60 days, 90 days and finally 110 days (Table 1). At 30 days maximum plant height was recorded in $\mathrm{T}_{4}(13.58 \mathrm{~cm})$ which was significantly superior than rest of the treatments followed by $\mathrm{T}_{7}(12.61 \mathrm{~cm})$ which remained at par with $\mathrm{T}_{10}(12.26 \mathrm{~cm})$. However, lowest height was recorded in $\mathrm{T}_{1}(9.75 \mathrm{~cm})$.

Similar results were also obtained with respect to height of plant at 60 days as well as 90 days where the highest heights were measured to be $42.61 \mathrm{~cm}$ and $53.26 \mathrm{~cm}$ respectively which was significantly higher than rest of treatments.

Maximum height was recorded in $\mathrm{T}_{4}(56.17$ $\mathrm{cm})$ after 110 days of planting which was significantly superior than other treatments. However, the lowest height was recorded in $\mathrm{T}_{1}(49.82 \mathrm{~cm})$ which was significantly inferior to other treatments tried in the experiment.

The result revealed that the plant height in Coriander was greatly influenced by combined application of $\mathrm{N}, \mathrm{P}, \mathrm{K} \&$ biofertilizers, which might be attributed to longer amount of sustained supply of nutrients during growth period. The greater increase in plant height may also be due to build-up colonies of applied bio-fertilizers inoculates and their growth promoting substances as reported by Tien et al., (1979) in pearl millet.

\section{Number of branches per plant}

Maximum no. of branches per plant was recorded in $\mathrm{T}_{4}$ (5.67) which was significantly higher than rest of the treatments followed by $\mathrm{T}_{7}$ (4.67) and $\mathrm{T}_{10}$ (4.33) (Table 1). However, the lowest no. of branches per plant was recorded in $\mathrm{T}_{1}$ (2.33) which was significantly inferior than rest of the treatments.

Combined effects of $100 \% \mathrm{~N}, \mathrm{P}, \mathrm{K}$ in combination with Azotobacter and Azospirillum resulted in production of maximum number of branches per plant. This clearly indicates that bio-fertilizers along with $\mathrm{N}, \mathrm{P}, \mathrm{K}$ got a cumulative effect in association with $\mathrm{N}_{2}$, thus enhancing its requirement by the crop.

\section{Number of leaves per plant}

Maximum number of leaves was recorded in 30 days of planting in $\mathrm{T}_{4}$ (8.87) which was significantly superior to all other treatments followed by $\mathrm{T}_{7}$ (8.13) and $\mathrm{T}_{10}$ (7.37) (Table 2 ). However, the lowest value was recorded in $\mathrm{T}_{1}$ (5.53).

Similar trend was also recorded on the leaf no. at 60 days of planting where $\mathrm{T}_{4}$ (12.37) was the highest and significantly superior than other treatments followed by $\mathrm{T}_{7}(11.43)$ and $\mathrm{T}_{10}$ (10.58). The lowest value was recorded in $\mathrm{T}_{1}$ (8.37) which is control.

Leaves are the major sites of photosynthesis. Production of leaf is generally influenced by environment as well as nutrition. The no. of leaves per plant showed significant variation due to various leaves of organic \& inorganic 
fertilizers. Azospirillum and Azotobacter in combination enhances the available nitrogen status which might helps in enhancing the photosynthesis activity (Pooja et al., 2017).

\section{Leaf area $\left(\mathrm{cm}^{2}\right)$}

Maximum leaf area was recorded in $\mathrm{T}_{4}(11.31$ $\mathrm{cm}^{2}$ ) which was significantly higher than rest of the treatments followed by $\mathrm{T}_{7}\left(10.72 \mathrm{~cm}^{2}\right)$ and $\mathrm{T}_{10}\left(10.20 \mathrm{~cm}^{2}\right)$ (Table 2). It was further observed that least leaf area was recorded with $\mathrm{T}_{1}\left(8.77 \mathrm{~cm}^{2}\right)$ which was significantly inferior to other treatments.

Leaf area expansion is one of the indications of response growth factor and also a direct indication of photosynthetic potentiality of a plant. Higher leaf area index is due to activity of Azotobacter \& Azospirillum that produce growth promoting hormones like IAA,GA or substances that increase $\mathrm{N}_{2}$ content in soil (Rangappa et al., 1997).

\section{Total chlorophyll (mg/g)}

The total chlorophyll content was maximum in $\mathrm{T}_{4}(1.17 \mathrm{mg} / \mathrm{g})$, which was significantly superior to rest of the treatments followed by $\mathrm{T}_{7}(1.13 \mathrm{mg} / \mathrm{g}) \& \mathrm{~T}_{10}(1.09 \mathrm{mg} / \mathrm{g})($ Table 2$)$.

However, lowest total chlorophyll content of leaf was observed in $\mathrm{T}_{1}(1.04 \mathrm{mg} / \mathrm{g})$ which was significantly inferior to all other treatments tried in experiment.

The combined effects of Azotobacter and Azospirillum has helped to absorb more amounts of available nutrients utilized for different growth parameters like plant height, number of branches per plant as well as chlorophyll content of leaves.

The chlorophyll content will ultimately be utilized for production of more no. of food material which will be exhibited in the form of plant height, leaf number etc. there by resulting more of vegetative growth i.e. yield (Nagar et al., 2009).

\section{Leaf yield}

A significant variation was marked in the yield of the coriander leaf which was taken in 30 days, 60 days and 90 days (Table 3). Maximum yield was recorded in $\mathrm{T}_{4}(375.67 \mathrm{~g}$, $384.67 \mathrm{~g}, 288.33 \mathrm{~g})$ which was significantly higher than rest of the treatments. However, the lowest yield was recorded with $\mathrm{T}_{1}$ $(190.67 \mathrm{~g}, 214.33 \mathrm{~g}, 140.67 \mathrm{~g})$ which was statistically inferior to rest of the treatments tried in the experiment.

Data revealed that maximum yield was recorded with $\mathrm{T}_{4}(1048.67 \mathrm{~g})$ which was significantly higher than all the treatments followed by $\mathrm{T}_{7}(941.99 \mathrm{~g}), \mathrm{T}_{10}(890.33 \mathrm{~g})$. The lowest value was recorded with $\mathrm{T}_{1}(541.67 \mathrm{~g})$. A significant variation was marked in total yield $(\mathrm{q} / \mathrm{ha})$ in all the treatments.

The maximum yield was observed in $\mathrm{T}_{4}$ (26.22 q/ha)) which was significantly higher than rest of treatments tried followed by $\mathrm{T}_{7}$ (23.55 q/ha) and $\mathrm{T}_{10}(22.26 \mathrm{q} / \mathrm{ha})$. However, lowest value was marked in $\mathrm{T}_{1}(13.61 \mathrm{q} / \mathrm{ha})$ which was significantly inferior to rest of the treatments.

The increase in yield might be due to increased supply of major plant nutrients that are required in huge quantities for growth and development of the plant. Azotobacter and Azospirillum fix atmospheric $\mathrm{N}_{2}$ which accelerate fast cell division, cell multiplication, cell elongation, protein \& protein synthesis in plants.

The plant treated with bio-fertilizer becomes more active and enable to synthesize required amount of hormones to promote leaf production thereby increasing leaf yield (Aishwath et al., 2010). 
Table.1 Effect of biofertilizers on plant height \& no. of branches per plant of coriander

\begin{tabular}{|c|c|c|c|c|c|c|}
\hline \multirow{2}{*}{\multicolumn{2}{|c|}{ Treatments }} & \multicolumn{4}{|c|}{ Plant height (cm) } & \multirow{3}{*}{$\begin{array}{c}\begin{array}{c}\text { No. of } \\
\text { branches }\end{array} \\
\text { per plant } \\
2.33\end{array}$} \\
\hline & & \multirow{2}{*}{$\begin{array}{c}\begin{array}{c}30 \\
\text { days }\end{array} \\
9.75\end{array}$} & \multirow{2}{*}{$\begin{array}{c}\begin{array}{c}60 \\
\text { days }\end{array} \\
38.52\end{array}$} & \multirow{2}{*}{$\begin{array}{c}\begin{array}{c}90 \\
\text { days }\end{array} \\
47.73\end{array}$} & \multirow{2}{*}{$\begin{array}{c}\text { Total } \\
\text { (110 days) } \\
49.82\end{array}$} & \\
\hline $\mathbf{T}_{1}$ & $100 \% \mathrm{RDF}$ & & & & & \\
\hline $\mathbf{T}_{2}$ & $100 \% \mathrm{RDF}+$ Azotobacter & 11.56 & 40.62 & 51.55 & 53.39 & 3.67 \\
\hline $\mathbf{T}_{3}$ & $100 \% \mathrm{RDF}+$ Azospirillum & 10.44 & 40.18 & 51.35 & 53.70 & 3.67 \\
\hline $\mathbf{T}_{4}$ & $\begin{array}{l}100 \% \mathrm{RDF}+\text { Azotobacter }+ \\
\text { Azospirillum }\end{array}$ & 13.58 & 42.61 & 53.26 & 56.17 & 5.67 \\
\hline $\mathbf{T}_{5}$ & $75 \% \mathrm{RDF}+$ Azotobacter & 11.48 & 40.31 & 50.79 & 52.07 & 3.33 \\
\hline $\mathbf{T}_{6}$ & $75 \%$ RDF + Azospirillum & 10.98 & 39.77 & 48.96 & 51.18 & 3.33 \\
\hline $\mathbf{T}_{7}$ & $75 \%$ RDF + Azotobacter + Azospirillum & 12.61 & 41.87 & 52.87 & 54.90 & 4.67 \\
\hline $\mathbf{T}_{8}$ & $50 \% \mathrm{RDF}+$ Azotobacter & 10.91 & 39.41 & 49.37 & 51.37 & 2.67 \\
\hline $\mathbf{T}_{9}$ & $50 \% \mathrm{RDF}+$ Azospirillum & 11.06 & 38.89 & 48.59 & 50.30 & 2.67 \\
\hline \multirow[t]{4}{*}{$T_{10}$} & $50 \% \mathrm{RDF}+$ Azotobacter + Azospirillum & 12.26 & 41.32 & 52.43 & 53.80 & 4.33 \\
\hline & Mean & 11.46 & 40.35 & 50.69 & 52.67 & 3.63 \\
\hline & $\mathrm{SE}(\mathrm{M})$ & 0.22 & 0.33 & 0.57 & 0.42 & 0.29 \\
\hline & C.D (0.05) & 0.65 & 1.41 & 1.68 & 1.26 & 0.87 \\
\hline
\end{tabular}

Table.2 Effect of biofertilizers on leaf no. (30 and 60 days), leaf area and total chlorophyll content of leaf of coriander

\begin{tabular}{|c|c|c|c|c|c|c|}
\hline \multirow{2}{*}{\multicolumn{2}{|c|}{ Treatments }} & \multicolumn{4}{|c|}{ Yield (g/plot) } & \multirow{3}{*}{$\begin{array}{l}\text { Total } \\
\text { Yield } \\
\text { (q/ha) }\end{array}$} \\
\hline & & \multirow{2}{*}{$\begin{array}{c}\left(\begin{array}{c}(30 \\
\text { days })\end{array}\right. \\
190.67\end{array}$} & \multirow{2}{*}{$\begin{array}{c}\left(\begin{array}{c}60 \\
\text { days })\end{array}\right. \\
214.33\end{array}$} & \multirow{2}{*}{$\begin{array}{c}\begin{array}{c}(90 \\
\text { days })\end{array} \\
140.67\end{array}$} & \multirow{2}{*}{$\begin{array}{l}\text { Total } \\
545.67\end{array}$} & \\
\hline $\mathbf{T}_{1}$ & $100 \% \mathrm{RDF}$ & & & & & \\
\hline $\mathbf{T}_{2}$ & $100 \% \mathrm{RDF}+$ Azotobacter & 275.33 & 284.67 & 226.67 & 786.67 & 20.03 \\
\hline $\mathbf{T}_{3}$ & $100 \%$ RDF + Azospirillum & 282.33 & 298.33 & 232.33 & 812.99 & 20.33 \\
\hline $\mathbf{T}_{4}$ & $100 \% \mathrm{RDF}+$ Azotobacter + Azospirillum & 375.67 & 384.67 & 288.33 & 1048.67 & 26.22 \\
\hline $\mathbf{T}_{5}$ & $75 \% \mathrm{RDF}+$ Azotobacter & 248.33 & 270.33 & 207.67 & 726.33 & 18.16 \\
\hline$T_{6}$ & $75 \%$ RDF + Azospirillum & 230.67 & 246.67 & 188.33 & 665.67 & 16.64 \\
\hline $\mathbf{T}_{7}$ & $75 \%$ RDF + Azotobacter + Azospirillum & 328.33 & 353.33 & 260.33 & 941.99 & 23.55 \\
\hline $\mathbf{T}_{8}$ & $50 \% \mathrm{RDF}+$ Azotobacter & 215.33 & 235.33 & 180.67 & 631.33 & 15.78 \\
\hline $\mathbf{T}_{9}$ & $50 \% \mathrm{RDF}+$ Azospirillum & 206.67 & 223.33 & 168.67 & 598.67 & 14.97 \\
\hline \multirow[t]{4}{*}{$\mathbf{T}_{10}$} & $50 \% \mathrm{RDF}+$ Azotobacter + Azospirillum & 316.33 & 331.67 & 242.33 & 890.33 & 22.26 \\
\hline & Mean & 266.97 & 284.27 & 213.60 & 764.83 & 19.16 \\
\hline & $\mathrm{SE}(\mathrm{M})$ & 6.48 & 4.53 & 3.82 & 8.03 & 0.22 \\
\hline & C.D(0.05) & 19.26 & 13.47 & 11.34 & 23.85 & 0.67 \\
\hline
\end{tabular}


Table.3 Effect of biofertilizers on yield (30, 60 and 90 days) of coriander

\begin{tabular}{|c|c|c|c|c|c|}
\hline & Treatments & $\begin{array}{l}\text { Leaves / } \\
\text { plant } \\
\text { (30 days) }\end{array}$ & $\begin{array}{c}\text { Leaves / } \\
\text { plant } \\
\text { (60 days) }\end{array}$ & $\begin{array}{l}\text { Leaf } \\
\text { area } \\
\left(\mathrm{cm}^{2}\right)\end{array}$ & $\begin{array}{c}\text { Total } \\
\text { Chlorophyll } \\
\text { Content of } \\
\text { Leaf }(\mathrm{mg} / \mathrm{g})\end{array}$ \\
\hline$T_{1}$ & $100 \% \mathrm{RDF}$ & 5.53 & 8.37 & 1.04 & 8.77 \\
\hline $\mathbf{T}_{2}$ & $100 \%$ RDF + Azotobacter & 7.13 & 10.3 & 1.09 & 10.13 \\
\hline $\mathbf{T}_{\mathbf{3}}$ & $\begin{array}{l}100 \% \mathrm{RDF}+ \\
\text { Azospirillum }\end{array}$ & 6.70 & 9.93 & 1.08 & 9.88 \\
\hline $\mathbf{T}_{4}$ & $\begin{array}{l}100 \% \text { RDF + Azotobacter } \\
+ \text { Azospirillum }\end{array}$ & 8.87 & 12.37 & 1.17 & 11.31 \\
\hline $\mathbf{T}_{5}$ & $75 \%$ RDF + Azotobacter & 6.57 & 9.17 & 1.09 & 9.69 \\
\hline$T_{6}$ & $75 \%$ RDF + Azospirillum & 6.43 & 8.9 & 1.08 & 9.53 \\
\hline $\mathbf{T}_{7}$ & $\begin{array}{l}75 \% \mathrm{RDF}+\text { Azotobacter } \\
+ \text { Azospirillum }\end{array}$ & 8.13 & 11.43 & 1.13 & 10.72 \\
\hline $\mathbf{T}_{8}$ & $50 \% \mathrm{RDF}+$ Azotobacter & 6.13 & 8.9 & 1.06 & 9.17 \\
\hline $\mathbf{T}_{9}$ & $50 \% \mathrm{RDF}+$ Azospirillum & 6.07 & 9.03 & 1.07 & 9.03 \\
\hline \multirow[t]{4}{*}{$\mathbf{T}_{10}$} & $\begin{array}{l}50 \% \mathrm{RDF}+\text { Azotobacter } \\
+ \text { Azospirillum }\end{array}$ & 7.37 & 10.58 & 1.09 & 10.20 \\
\hline & Mean & 6.89 & 9.9 & 1.09 & 9.84 \\
\hline & $\mathrm{SE}(\mathrm{M})$ & 0.22 & 0.15 & 0.01 & 0.17 \\
\hline & C.D(0.05) & 0.66 & 0.43 & 0.03 & 0.49 \\
\hline
\end{tabular}

Application of different levels of $\mathrm{N}, \mathrm{P}$ and $\mathrm{K}$ in combination with bio- fertilizers increased the vegetative part yield per plant, thereby increasing yield per hectare. Maximum yield of $26.22 \mathrm{q} / \mathrm{ha}$ was recorded by using $100 \%$ recommended dose of chemical fertilizers along with bio-fertilizers i.e. Azotobacter and Azospirillum.

The highest yield of this treatment was the sum total effect of different yield attributing characters particularly height of plant, number of branches, number of leaves etc. However, other biometric observations exhibited higher values because growth characters also top the list in this experiment. Yield per unit area also increased significantly over control but combined effects of bio-fertilizers boosted the yield attributing characters to exhibit maximum level which in turn produced highest yield (vegetative part).

\section{References}

Aishwath, O.P., Mehta, R.S. and Anwer, M.M., 2010.Integrated nutrient management in seed spice crops. Indian J. Fertilisers, 6(11): 132-139.

Gaur, A.C., 1990. Phosphate solubilizing microorganisms as biofertilizers. Omega Scientific Publishers. New Delhi, 198p.

Nagar, R.K., Meena, B.S. and Dadheech, R.C., 2009. Effect of integrated weed and nutrient management on weed density, productivity and economics of coriander (Coriandrum sativum). Indian J. Weed Sci., 41(1/2): 71-75.

Panse, V.G. and Sukhatme, P.V., 1985. Statistical Methods for Agricultural 
Workers. Indian Council Agric. Res. Pub., 87-89.

Pooja, G., Ananthan, P.S., Krishnan, M., 2017. Fish Farmers Development Agencies and Farmers Empowerment: An Impact Assessment Study in Uttar Pradesh. Agric. Econ. Res. Rev., 30(1): $113-124$.

Prabhu, T., Narwadkar, P.R., Sajindranath, A.K. and Rathod,N.G., 2001.Effect of integrated nutrient management on growth and yield of coriander (Coriandrum sativum L.). South Indian Hort., 50(4-6): 680-684.

Rangappa, M., Bhardwaj, H.L., Showhda, M. and Hamama, A.A., 1997.Cilantro response to nitrogen fertilizer rates. $J$. Herbs. Spices. Med. Plants., 5:63-68.

Shreekumar, B., 1997. Production and export of seed spices with special reference to Rajasthan. Spice India, 7: 8-12.

Singh, V.B. and Singh, K., 1996.Spices.New Age Int. Pvt. Ltd. Pub., New Delhi, 100112.

Tien, T.M., Gaskins, M.H. and Hubbell, D.H., 1979. Plant growth substances produced by Azospirillum brasilense and their effect on the growth of pearl millet (Pennisetum americanum L.). Appl. Environ. Microbiol., 37: 1016-1024.

\section{How to cite this article:}

Asim Abhishek Swain, Debi Archana Nayak, Premananda Mahapatra, Alok Nandi, Nitish Kumar Jena and Janmejaya Panda. 2020. Effect of Bio-fertilizers on Growth and Leaf Yield of Coriander (Coriandrum sativum L.). Int.J.Curr.Microbiol.App.Sci. 9(04): 826-832. doi: https://doi.org/10.20546/ijcmas.2020.904.099 